\title{
A LÍNGUA FRANCA DO SUPRASSENSÍVEL: SOBRE XAMANISMO, CRISTIANISMO E TRANSFORMAÇÃ ${ }^{*}$
}

\author{
Artionka Capiberibe
}

La palabra ch'ixi tiene diversas connotaciones: es un color producto de la yuxtaposición, en pequeños puntos o manchas, de dos colores opuestos o contrastados: el blanco y el negro, el rojo y el verde etc. Es ese gris jaspeado resultante de la mezcla imperceptible del blanco y el negro, que se confunden para la percepción sin nunca mezclarse del todo. La noción ch'ixi, como muchas otras (allqa, ayni), obedece a la idea aymara de que algo es y no es a la vez, es decir, a la lógica del tercero incluido (Silvia R. Cusicanqui 2010:69).

"Conta um velho manuscrito beneditino que o Diabo, em certo dia, teve a ideia de fundar uma igreja. Embora os seus lucros fossem contínuos e grandes, sentia-se humilhado com o papel avulso que exercia desde séculos, sem organização, sem regras, sem cânones, sem ritual, sem nada. Vivia, por assim dizer, dos remanescentes divinos, dos descuidos e obséquios humanos. Nada fixo, nada regular. Por que não teria ele a sua igreja? Uma igreja do Diabo era o meio eficaz de combater as outras religiões, e destruí-las de uma vez".

Assim começa o conto "A Igreja do Diabo", de Machado de Assis. A história traz uma alegoria sobre o bem e o mal, construída por meio da imagem de uma capa de veludo, tecido que simboliza as boas virtudes, finalizada por franjas de algodão, que são a maldade imanente ao humano; puxadas estas franjas, o veludo desaparece e temos uma capa de algodão que, por sua vez, é finalizada por franjas de seda, a seda simbolizando a bondade humana. Depois de ter prevenido Deus sobre a concorrência futura, o diabo apresenta as "virtudes" necessárias aos fiéis de sua Igreja: a soberba, a luxúria, a preguiça, a inveja, a ira, a gula, a fraude, a venalidade, a hipocrisia, a adulação etc. Logo a Igreja prosperou e fez sucesso. No entanto, com o passar do tempo, o diabo deu-se conta de que seus fiéis, de maneira sorrateira e escondida, traíam os preceitos da Igreja: "o amor ao próximo" era um obstáculo grave à sua instituição. Acabrunhado, foi então queixar-se a Deus sobre a infidelidade de seus fiéis, ao que Deus placidamente respondeu: 
- Que queres tu, meu pobre diabo? As capas de algodão têm agora franjas de seda, como as de veludo tiveram franjas de algodão. Que queres tu? É a eterna contradição humana.

O belo conto machadiano serve aqui como metáfora da dualidade mudança/continuidade que está sempre subentendida nas análises antropológicas sobre processos de transformação e, no caso dos estudos sobre religiões cristãs em populações indígenas, costuma ser refraseada em polaridades dicotômicas, como indivíduo/sociedade, cristianismo/xamanismo, crença/prática, fé/superstição, religião/magia. Contudo, a antinomia com mais rendimento analítico continua sendo estrutura/evento (M. Sahlins 1985). ${ }^{1}$ E se essas polaridades não estão explícitas nas análises antropológicas, elas são invariavelmente o pós-fato, no sentido de Strathern (1992), isto é, o fundo dado sobre o qual se imprime a figura da análise.

O problema dos dualismos para pensar este tema é pô-los como antíteses e eleger sempre um dos polos como lócus explicativo; com isso, é quase inevitável esbarrar em contradições. Melhor seguir a advertência de Deus ao Diabo e não lutar contra estas, ou melhor, contra aquilo que pode parecer uma contradição, mas que, em realidade, é a própria condição de existência do fenômeno, constituído simultaneamente por convenções e invenções num uso particular da formulação de Roy Wagner (2010). ${ }^{2}$

A partir da relação entre um fenômeno de possessões, denominado crise, e o cristianismo presente entre algumas populações indígenas da região do baixo rio Oiapoque, este artigo pretende mostrar que, para entender um evento deste gênero, é preciso sair do princípio da dualidade, uma ordem lógica posta e reposta pelo pensamento antropológico - como dito, às vezes de maneira subliminar. A proposta avançada aqui é a de que os fenômenos sociais não são objetos com contornos perfeitamente definidos, são ao mesmo tempo coisas corporais, metafísicas e afetivas. A conjunção de corpos/ideias/ afetos ganha significação em (e na) relação pelas conexões que se estabelecem e pelas conexões que carregam, de relações precedentes, os elementos em conexão. Para o tema que nos ocupa, esta proposta está plasmada na noção de língua franca do suprassensível a ser aqui definida e explorada.

No baixo rio Oiapoque, região Amazônica marcada pela fronteira entre o Brasil e a Guiana Francesa, entre outras línguas, fala-se, há séculos, o créole, língua franca proveniente do francês, que é a própria corporificação de "invenção" (Wagner 2010). No entanto, a língua franca de que vai tratar este artigo é uma linguagem que se constitui num sistema de ideias, afetos 
e práticas. Trata-se de um tipo de comunicação estabelecida em (e com) um plano suprassensível, por meio daquilo que é conhecido genericamente como xamanismo indígena e por diferentes versões do cristianismo presente nessa região há tempos. Como veremos, tal linguagem movimenta (e se movimenta) pelos corpos postos em relação. Nessas relações, sentidos são criativamente gerados.

O olhar da antropologia sobre a cristianização de populações nativas não é propriamente uma novidade, ${ }^{3}$ sendo hoje objeto de interpretações e debates teóricos distintos e mesmo conflitantes entre si. ${ }^{4}$ Destes debates depreende-se que se trata de um fenômeno complexo, marcado pelo encontro entre a própria diversidade interna à religião cristã e os contextos locais em que se insere e se desenvolve, ${ }^{5}$ o que resulta numa variedade de tipos de cristianismos.

A falta de um modelo monolítico e o reconhecimento que as igrejas dão às mais diferentes formas de religiosidade cristã sustentadas pelos povos nativos fazem pensar que o que se passa é uma espécie de transformação de mão dupla. Nas populações indígenas das terras baixas da América do Sul, essa transformação se expressa na criação de significados produzidos na relação entre o cristianismo e a sociocosmologia nativa, ${ }^{6}$ mas isto não é algo totalmente extraordinário se concebermos tal transformação como parte de um contínuo e incessante movimento de alteração. ${ }^{7}$ Este encontro produz uma sorte de "bricolagem intelectual", tomando emprestado o sentido dado por Lévi-Strauss à lógica da construção do mito, pela qual se opera um constante (re)arranjo de elementos que, como a cada volta do caleidoscópio, vão ganhando novas tonalidades e sentidos dentro do conjunto original que irão formar. ${ }^{8}$ Nos termos de Lévi-Strauss, " [...] os significados tornam-se significantes e inversamente." (1976:42). Aqui, os significantes são os próprios corpos. São eles que dançando, sendo possuídos, privando-se de alguns prazeres vão criar um novo significado e revelar na Igreja nascente uma estrutura, em muitos sentidos, pré-existente.

O caso que servirá de exemplo para pensar essa bricolagem intelectual do cristianismo e, ao mesmo tempo, expor a ideia de língua franca do suprassensível é um fenômeno que os indígenas que habitam a região do baixo rio Oiapoque nomearam, em português e de maneira bem sugestiva, de crise. Trata-se de uma eclosão de ataques de espíritos que ocorre dentro e fora das igrejas cristãs presentes na área indígena e cuja característica marcante é a de atingir primordialmente pessoas jovens.

Este fenômeno me parece expressar fundamentalmente um regime de "relações", ${ }^{9}$ inserindo-se na lógica nativa segundo a qual relações constituem corpos, produzidos por aproximações e diferenciações sociologicamente significantes. São os relacionamentos que fazem pessoas humanas e/ou não 
humanas, que distinguem parentes consanguíneos de afins, que estabelecem categorias etárias, diferenças de gêneros etc., porque nenhum contorno ou limite é dado aprioristicamente. ${ }^{10}$

O debate sobre ontologias ameríndias, que vem mobilizando discussões há cerca de duas décadas, trouxe como um fato a ideia de que, em muitos povos indígenas, humanos e não humanos (animais, espíritos de animais, heróis fundadores, mortos etc.) detêm um mesmo estatuto de "pessoa". ${ }^{11}$ A humanidade ou a não humanidade dos sujeitos é não só relativa, como relacional (frase presente em vários escritos de Viveiros de Castro que tomo emprestada de maneira livre). A mitologia palikur, um dos povos envolvidos na crise, está repleta de narrativas sobre encontros interespecíficos fortuitos na mata, nos quais um animal avista um humano como uma presa animal e termina capturando-o e levando-o para seu mundo, onde ambos passam a viver uma vida nos moldes da cultura humana - é, como se nota, uma expressão do perspectivismo ameríndio teorizado por Viveiros de Castro (2002) e Stolze Lima (1996). Num mundo em que ser pessoa e possuir cultura não são prerrogativas exclusivas de homens e mulheres, mas qualidades extensivas aos não humanos, o que se passa quando nas relações entram outros tipos de seres? Tais como Deus e o diabo? ${ }^{12}$

\section{O socius da crise}

Desde o século XVI, a história da região do baixo rio Oiapoque é povoada por uma multiplicidade de não indígenas ${ }^{13}$ e uma diversidade ainda maior de populações indígenas. ${ }^{14} \mathrm{~A}$ atual ocupação desta região é testemunha do massacre infligido pela colonização, estando reduzida a apenas quatro povos: os Palikur, que falam o parikwaki, uma língua da família maipurearawak; os Galibi-Kali'na, cujo idioma é filiado à família linguística carib; os Galibi-Marworno e os Karipuna, ambos falantes de variações do créole, às quais dão o mesmo nome de patois. Todos estes povos compreendem ou falam, em medidas diferentes, as línguas provenientes das relações com os não indígenas: português, francês e créole.

Outros povos indígenas que habitam mais ao alto do rio Oiapoque também circulam pela região, mas aqui irei trabalhar a crise conforme me foi relatada por interlocutores galibi-marworno e, principalmente, palikur e karipuna. O foco da análise será também delimitado ao território no qual travei contato com o tema em discussão, ou seja, a Terra Indígena Uaçá, ${ }^{15}$ localizada no lado brasileiro da fronteira, que é norteada pela bacia hidrográfica do Oiapoque, tendo como tributário direto o rio Uaçá, no qual desembocam dois outros rios, o Urukauá e o Curipi. 
No lado brasileiro da fronteira, os Palikur são cerca de 1.300 pessoas e vivem em mais de uma dezena de aldeias ao longo do rio Urukauá. No rio Curipi, ficam os Karipuna, população com cerca de 2.500 pessoas também distribuída em várias aldeias. E, por fim, no rio Uaçá vivem os Galibi-Marworno, com uma população de aproximadamente 2.400 pessoas, quase toda concentrada numa única aldeia, Kumarumã. ${ }^{16}$ Esses povos também têm famílias vivendo em bairros das cidades fronteiriças de Oiapoque e Saint-Georges. ${ }^{17}$

Quanto às religiões cristãs, o que se pode assegurar é que, afora uma menção sobre a existência fugaz de missões jesuíticas francesas no século XVIII (J-M. Hurault 1972; E. Fauque 1993), a Igreja Católica se estabeleceu na região com a instalação da igreja matriz de Oiapoque, em 1948 (Capiberibe 2009:56). Todavia, a atuação dos padres, até os anos 1970, foi marcada pela irregularidade de suas presenças dentro da área indígena, sobretudo porque trabalhavam na lógica das viagens de "desobriga". ${ }^{18}$ A partir de meados da década de 1970, a paróquia de Oiapoque passou a ser ligada ao Conselho Indigenista Missionário (CIMI) e a seguir a teologia da inculturação, estando bastante voltada a uma ação política e social, além da religiosa. ${ }^{19}$

O catolicismo presente entre os Karipuna e os Galibi-Marworno é marcado pelas festas feitas aos santos. Entre os Galibi-Marworno, a caracterização do católico está relacionada principalmente aos ritos ligados ao ciclo de vida: o batismo, a possibilidade de casar-se na Igreja, receber as exéquias religiosas e ter um funeral apropriado. O ápice de seu catolicismo concentra-se na festa para Santa Maria, composta por procissões, missas, ladainhas, torneios de futebol, som de festa profana, presença de não índios (franceses, brasileiros, guianenses) e políticos da região. ${ }^{20}$ Já entre os Karipuna, o catolicismo das festas dedicadas aos santos, que se assemelham a essa festa galibi-marworno, convive em paralelo com rituais xamanísticos.

Mais recentemente, a partir dos anos 2000, uma Igreja Batista (protestante, não pentecostal) se instalou entre os Galibi-Marworno. Nos Karipuna, quem entrou foi a Assembleia de Deus. Embora o pentecostalismo não seja um elemento da Igreja Batista, a atuação desta entre as populações indígenas é guiada pelo mesmo ímpeto salvacionista das Igrejas pentecostais, prática fortemente relacionada a uma expectativa escatológica. É esta expectativa que parece fornecer chão para o desenvolvimento dos "avivamentos espirituais" que se vê hoje nesta área indígena, marcados principalmente por: emotividades, êxtases religiosos (entre os pentecostais), possessões espirituais, mudanças comportamentais e o impulso para a evangelização de outros indígenas. ${ }^{21}$ 
Até 1965, os Palikur encontravam-se inseridos no sistema católico de festas de santo. Mas com a chegada de um casal de missionários linguistas norte-americano do Summer Institute of Linguistics (SIL) naquele ano, eles passaram a ser alvo de ações mais coordenadas e intensas de proselitismo religioso evangélico. O passado católico é hoje qualificado de maneira negativa, sendo acusado de não permitir uma proximidade substantiva com o Deus cristão, como se pode ver em um diálogo ocorrido no início das minhas pesquisas de campo e até hoje repetido das mais diversas formas:

Mbagui: Artionka, você é crente?

Artionka: Não.

Mbagui: Eu sou crente, mas antes era católico, acreditava nos santos. Um dia, eu sonhei, e no meu sonho veio um homem e me disse: "Tu achas que o santo fala contigo? Não fala. Ele tem boca, mas não fala, ele tem ouvido, mas não ouve" (Kumenê 1996).

Para os Palikur, os sonhos são capazes de interferir no mundo da matéria. Eles fazem parte de um conjunto de elementos que têm a capacidade de transitar entre as coisas, as pessoas e os espaços do mundo sensível e as coisas, pessoas e espaços que constituem e ocupam outros mundos, os quais estão não só em conexão com o nosso mundo "terreno", como compartilham da cultura que o move (veja-se a noção de pessoa introduzida no início deste texto e, infra, a descrição sucinta desses mundos) ${ }^{22}$

Os relatos do evento de conversão, espécie de mito fundador da religião evangélica entre os Palikur, apontam sempre para um elemento que, como os sonhos, faz parte de um mundo que está para além do sensível. Trata-se do êxtase religioso, o encontro íntimo com o Espírito Santo. ${ }^{23}$ A esse contato, os Palikur atribuem a força que fez com que as pessoas deixassem de beber bebidas alcoólicas, de brigar entre si e passassem a se reunir e a viver num mesmo espaço em comum, ${ }^{24}$ começando a acreditar na existência concreta de Deus. Essa crença está relacionada a um modo de conhecimento que se ancora nos sentidos e se constitui na experimentação (A. Capiberibe 2007:200-204).

Logo após o evento da conversão, os Palikur procuraram a Igreja Evangélica Assembleia de Deus nas cidades próximas e a introduziram no Urukauá. ${ }^{25}$ A Assembleia de Deus tem como pilares basilares a busca pelo contato com o Espírito Santo e a "leitura da palavra". Como padrão de estética, segue o vestuário usado pelos missionários suecos que a fundaram no Brasil: terno para os homens, vestidos longos e cabelos compridos para as mulheres. 
E como normas de conduta, não beber, não fumar, não dançar e, às vezes, não jogar futebol. Todos estes "costumes comportamentais", para usar uma expressão de Freston (1994:126), encontram-se entre os assembleianos palikur, inclusive a proibição de jogar futebol.

\section{A crise}

"Crise", no dicionário de língua portuguesa Houaiss, tem pelo menos 12 acepções, as quais podem ser agrupadas em dois grandes temas: por um lado, o termo está relacionado a aspectos fisiológicos e psíquicos, descrevendo o momento decisivo de uma doença, para a vida ou para a morte, assim como estados de desequilíbrios emocionais e/ou nervosos. Por outro lado, esta palavra está conectada ao campo de ações sociais, qualificando desequilíbrios conjunturais que podem se dar na área econômica (entre produção e consumo, por exemplo) ou em situações políticas de tensão momentânea com disputas agudas e conflitos.

Como veremos, os significados e as consequências atribuídas ao termo "crise", no contexto do baixo Oiapoque, põem em relevo tanto aspectos fisiológico-psíquicos como sociais.

A crise consiste na emergência de alguma forma de entidade espiritual que se apossa do corpo das pessoas, mas principalmente daqueles dos/das jovens. Isso faz com que as pessoas ajam violentamente, colocando suas próprias vidas em risco e a vida de quem estiver à sua volta. Este é o quadro recorrente nas narrativas. ${ }^{26}$

O fenômeno é descrito, principalmente por pessoas adultas, como violento, visto como perigoso e causador de tristeza e medo. Ele parece provocar uma espécie de ruptura com um estado de convivência social, por meio de uma suspeição que rondaria a sociabilidade, isto é, as relações sociais empáticas e afetivas que conformam a comunidade, ${ }^{27}$ como se vê no seguinte relato:

F. - [...] passei trabalho em grupo aos alunos e notei que os jovens de um dos grupos ficavam olhando para uma menina, como se a estivessem vigiando, quando ela caiu, eles já estavam prontos para segurá-la (Galibi-Marworno, aldeia palikur de Kumenê, 2013). ${ }^{28}$

Este "cair" é literalmente se transformar, agir como o espírito que se apossou de si, assumir o corpo do espírito e se tornar Outro para os seus, alterar-se na relação, como num encontro ao acaso com um predador na mata. Na fala a seguir, isto fica explícito, pois quem é possuído vê seus iguais como diferentes: 
V. - É uma tristeza muito grande para os familiares, porque a pessoa ficava se jogando, se batendo e tinha que segurar ela com força senão... se ela pegasse uma faca, podia furar a gente. É porque as pessoas achavam, na visão delas, que a gente tava atacando, que a gente é que era o agressor. Quem tava possuído achava que, como a gente se aproximava, que a gente é que era o bicho, era o demônio, era tudo (Karipuna, aldeia karipuna de Santa Isabel, 2013).

O perigo que a crise significa também é diretamente associado a uma ideia de contágio, que se daria pela nominação da "próxima vítima":

N. - Por exemplo, eu fui possuído, aí eu tô aqui no chão e de repente eu chamo o teu nome, aí tu vai ser possuída pelo diabo também (Palikur, aldeia palikur de Kumenê, 2013).

Isto explicaria o alastramento da crise e o surgimento de uma verdadeira epidemia, noção que ganha força quando as narrativas descrevem o percurso geográfico seguido pelos ataques:

F. - Por um mês, no ano passado, fui dar aulas na aldeia de Kumarumã [aldeia Galibi-Marworno], mas não levei minha mulher, nem meu filho por causa da crise. Esse negócio foi muito forte lá. Depois foi a vez do Manga [aldeia Karipuna], agora está bem espalhado no Curipi [rio no qual se concentram as aldeias karipuna] (Galibi-Marworno, aldeia palikur de Kumenê, 2013).

V. - A gente percebe que alguma coisa não tá legal, porque se fosse só no Kumarumã... mas é uma coisa que tá voltada à região todinha, porque veio do Kumarumã, foi para o Manga, desceu [o rio] para o Santa Isabel, Espírito Santo. E agora também com vocês, né? [referindo-se ao senhor palikur que acompanhava a conversa e acabara de afirmar que o fenômeno havia ocorrido recentemente em sua aldeia] (Karipuna, aldeia karipuna de Santa Isabel, 2013).

Em 2013, o ápice da crise havia passado, mas as pessoas ainda estavam construindo uma explicação para o fenômeno. Nessa construção, surgiram também inferências sobre um possível desequilíbrio emocional e/ou nervoso, mas sempre pouco vigorosas, colocadas mais como dúvida. O titubeio pode estar relacionado a uma tentativa de fornecer uma explicação que pudesse fazer sentido para mim (a interlocutora não indígena), uma vez que os indígenas não ignoram o universo etiológico dos brancos: ${ }^{29}$

N. - Ainda agora uma menina foi possuída, ela correu pro campo, aí o pessoal correu atrás. Aí eu falei, "eu não vou correr atrás, porque eu não dou conta pra segurar um diabo, o diabo tem muita força. [...]". Não sei se é uma doença. Eu tô pensando assim, uma doença mental, sei lá? Agora tá difícil pra descobrir que coisa é essa (Palikur, aldeia palikur de Kumenê, 2013). 
Minha própria condução das conversas pode ter induzido a este tipo de resposta:

Artionka - E não dá para imaginar que isso esteja na cabeça dos jovens?

V. - Não, no início a gente percebeu isso, que as mentes estavam fracas. Aí depois a gente não tinha mais explicação pra nada, aí a gente ficou preocupado... mas acho que não, não era mente fraca, porque tinha algumas pessoas que se transformavam. Aí a gente achou que era um espírito mesmo... pesado... que tava entrando nas pessoas e que a gente tinha que reagir, tinha que frear esse espírito (Karipuna, aldeia karipuna de Santa Isabel, 2013).

Embora não houvesse muitas certezas de como interpretar fatos tão dramáticos, ouvi de diferentes interlocutores palikur a seguinte formulação explicativa. Para os adultos e as adultas, os jovens rapazes e moças estavam colocando o êxtase religioso - justamente o elemento determinante para a adesão, nos anos 1960, à religião pentecostal - em um lugar central demais. Aproximando-se de maneira excessiva e com pouco controle de um mundo que, se é desejado, é também temido, uma vez que permite a abertura do corpo a outros seres e mundos, ou melhor, a abertura do ganmap, a parte incorpórea que, junto com o aspecto físico (givit), constitui o corpo palikur. Em trabalho anterior (Capiberibe, A. 2014), expondo como o ganmap possibilita a comunicação interespecífica, apresento uma definição sobre o corpo palikur. Recupero-a aqui a fim de esclarecer o que é essa abertura:

O ganmap e o givit (corpo físico) constituem a "pessoa" palikur. Um sem o outro significa uma não pessoa. Nessa conjunção, o ganmap é aquilo que anima o corpo, que o faz vivo: "O ganmap é entendido como o ser falante dentro da própria pessoa. Quando a pessoa morre, esse ser falante se vai, deixando o corpo só. Isso quer dizer que seu espírito saiu, nós falamos assim: ganmap pese, quer dizer, 'seu espírito saiu', ou seja, aquele que fala saiu do corpo e subiu para o céu junto de Deus" (Awdy, Macapá 2007) (Capiberibe, A. 2014:188-9).

Esta me parece ser uma pista para entender por que a crise atinge primordialmente os jovens. Para responder a esta questão é preciso levar em conta que o baixo Oiapoque é uma região em que as relações entre indígenas e não indígenas são longevas e estão cada vez mais intensas, uma realidade comum a outras áreas indígenas no Brasil. A circulação dos jovens pelas cidades de Oiapoque e Saint-Georges, o acesso aos bens de consumo e a educação escolar formal são dados a serem considerados. Já ouvi de amigos e amigas palikur, incontáveis vezes e em situações diferentes, o que me disse um interlocutor karipuna ao organizar uma explicação para o fenômeno da 
crise: "na maioria das comunidades, hoje, um problema muito sério é o dos jovens. A gente está tendo muito acesso de muita coisa, né? E esses acessos estão contribuindo muitas vezes com partes positivas e muitas vezes com partes negativas". ${ }^{30}$

Esta concepção abrangente sobre o contato com as coisas dos não indígenas que contempla aspectos positivos e negativos parece-me conectada ao "regime de relações" de que falo no início deste texto. Em outras palavras, a rede de relações na região (de parentesco, casamento, políticas, econômicas, religiosas etc.) testemunha que se o estabelecimento de relacionamentos segue a máxima levistraussiana da abertura ao Outro, este fato também implica uma abertura do corpo a transformações, para o bem ou para o mal.

Mas isto só se torna uma explicação suficiente sobre o porquê de a crise atingir principalmente os jovens se levarmos em conta que ela não se restringe a eles exclusivamente, porque, ao afetá-los, ela afeta toda a rede de relações à qual estão ligados. Entendo aqui que aqueles que compõem a rede constituem-se uns aos outros, num sentido similar ao conceito melanésio de "divíduo", isto é, de que as pessoas "[...] contêm dentro de si uma socialidade generalizada. Com efeito, as pessoas são frequentemente construídas como o lócus plural e compósito das relações que as produzem. A pessoa singular pode ser imaginada como um microcosmo social [...]" (M. Strathern 2006:40-1).

Com isso, a explicação que toma como causa o contato com as "coisas dos brancos" também é mais ampla, não se limita aos jovens e aos não indígenas, mas fala de uma espécie de "senso de comunidade", tomando emprestada a expressão usada por Overing para compreender "o social" ameríndio. Na definição de Overing, esse "senso de comunidade" é "um senso do certo e do bem comum, que é adquirido através da vida em comunidade" (1991:7-8), sendo explorado pela autora a partir da associação entre uma noção de estética e um comportamento político e moral. Mas o "senso de comunidade" também poderia ser pensado a partir da ideia de que a convivialidade, a coabitação, a comensalidade e todos os atos que se praticam em comum (entre indivíduos ou entre grupos de indivíduos, consanguíneos e afins, por exemplo) são formadores de pessoas de estatutos sociológicos não só semelhantes, ${ }^{31}$ mas interconectados, pessoas ligadas entre si por esta rede de relações que as faz agirem segundo uma noção compartilhada sobre "o certo e o bem comum". A partir daí é possível imaginar os efeitos na socialidade indígena da introdução de novas relações, venham elas por meio de objetos-sujeitos ${ }^{32}$ (celulares, televisores, voadeiras, carros etc.), ou por meio de sujeitos-sujeitos (comerciantes, professores e professoras, prostitutas, policiais, exército etc.). 
No caso da crise, tudo se passa como se certos elementos (como os brancos e "as coisas dos brancos") enfraquecessem as relações interpessoais e, sobretudo, intergeracionais, pelo menos entre os Palikur, e com isso tornassem os jovens, justamente aqueles que estão em contato mais intenso com esses novos elementos (sujeitos/sujeitos e/ou objetos-sujeitos), suscetíveis aos ataques espirituais. Aqui a importância das "relações" para a noção de pessoa indígena é óbvia. O enfraquecimento das conexões com os mais velhos debilita as relações com os parentes humanos e, consequentemente, abre o corpo à atração de seres de outra espécie ou ordem.

Acompanho os cultos palikur desde 1996. Em 2013, notei que havia algo diferente nessas celebrações religiosas, pois alguns jovens que entravam em transe não pareciam estar sendo possuídos pelo Espírito Santo. Isto se comprovou quando vi que os pastores palikur estavam fazendo exorcismo nesses jovens durante os cultos e dentro da Igreja. É como se o significado do transe religioso estivesse se alargando e, no lugar de um contato exclusivo com o Espírito de Deus, abrindo caminho para outros tipos de comunicação. Essa mudança não só não passou despercebida para algumas pessoas, como causou inquietação. Um velho senhor palikur, comentando sobre a atitude dos jovens em relação à religião cristã, faz um alerta sobre as consequências disto:

M. - Eles [os jovens] não ouvem a palavra do pastor, só a do Espírito Santo. Isso não é bom, porque pode entrar o espírito santo, mas também o espírito mau (Palikur, aldeia de Kumenê, 2013).

Nos cultos, vê-se que os jovens estão voltando as costas para "as palavras"33 e, ao mesmo tempo, lançando-se com energia e fúria para dois outros aspectos da liturgia do ritual, a entoação de músicas e as danças que as acompanham, que estão diretamente relacionados ao transe religioso, o que é visto pelos mais velhos como "desrespeito" em relação aos pastores e mesmo a Deus. Na fala de um jovem adulto o "desrespeito" é qualificado como um erro dos jovens:

N. - [...] Aqui na igreja, quando o pastor prega a palavra de Deus, todo mundo vai saindo. Eles só gostam de cantar, dançar, tocar. Para eles é festa. Eles acham "ah tô lá numa casa de dança mesmo, uma boate", mas quando um pastor levanta para pregar a palavra, eles abaixam a cabeça e vão saindo, um por um. Quando o pastor deixa o microfone, todo mundo volta de novo pra dançar. Eu não gosto assim, tá errado (Palikur, aldeia palikur de Kumenê, 2013). 
Já para uma senhora de mais idade, que vi admoestando e, ao mesmo tempo, aconselhando os jovens para prestarem atenção na fala dos pastores, o desrespeito é diretamente com Deus. Diz ela: “[...] quando o pastor começa a falar a palavra de Deus, os jovens saem da igreja, vão passear. Assim, eles não aprendem a respeitar Deus, eles têm de saber que Deus é poderoso e que nós devemos respeito a ele, e só vão aprender isso se ouvirem a palavra de Deus. Não adianta só dançar" (R., Palikur, aldeia palikur de Kumenê, 2013).

Desrespeito é a forma pela qual é explicado o afastamento entre as gerações mais velhas e os jovens. Desrespeito é também uma transformação nessas relações. Transformação devida à entrada, na malha das relações estas pensadas de maneira ampla como sociais, morais, políticas e metafísicas - de novas situações, novos objetos e novos sujeitos.

Retorno novamente à ideia de "transformação" que acompanha o texto e fundamenta algumas de suas proposições. Sua definição se deve a Lévi-Strauss, mas também a uma releitura feita no projeto "Nuti-Pronex" - Museu Nacional/UFRJ, na primeira metade dos anos 2000, cujos contornos estão expostos de maneira mais evidente na conferência de Viveiros de Castro (2012) em seu concurso para professor titular. Neste texto, fica patente a relação proposta por Lévi-Strauss entre a noção de "transformação" e o "conjunto de afastamentos diferenciais" que constituem "cultura" (2012:164). Ao mesmo tempo, tais definições não perdem de vista o fato de serem estabelecidas pelas mãos das antropólogas e antropólogos e não dados da realidade social. Isso permite, nos termos de Viveiros de Castro:

[...] percorrer, por transformações topológicas contínuas, todos os diferentes esquemas conceituais, estilos de pensamento e formas de vida de que é capaz a espécie humana (e de passar dela a outras espécies pela mesma via), os quais - estilos, esquemas, formas - não são mais que pontos de cristalização historicamente transitórios e contingentes desse fluxo transformacional universal" (2012:164-65 - itálico do original).

Sem entrar na discussão que segue o autor sobre o "postulado da continuidade" presente nesta definição, interessa ressaltar a ideia, que se pode ler no texto, de que transformação não é outra coisa senão o modo default do vivido. Mas, se supomos que isso é um dado, ainda é preciso mostrar como ele se desenvolve. 


\section{Os sentidos da epidemia}

Para pensar como o fenômeno pôde se espraiar pelos diferentes povos, é importante considerar que a eclosão de possessões coincide também com a expansão de Igrejas evangélicas e pentecostais na área indígena, iniciada no primeiro quarto dos anos 2000. Nessa expansão, o procedimento das Igrejas pentecostais foi sendo transmitido, levando a diferentes aldeias uma linguagem comum, expressa principalmente pelo transe religioso do batismo com o Espírito Santo, cuja performance (gritos, tremores no corpo, desfalecimentos, glossolalia) costuma evocar a presença imediata de um mundo suprassensível. Os modos pelos quais essa linguagem tem sido apropriada são variados, mas, ao mesmo tempo, apontam para algo que é comum, a tal língua franca do suprassensível.

Essa língua de comunicação é o que me parece autorizar o uso de estratégias "religiosas" de origens diferentes para dar conta do "problema" da crise, aliando, para a "cura", as diversas Igrejas cristãs, o xamanismo indígena e mesmo práticas ligadas às religiões afro-brasileiras, como a umbanda. Veja-se o seguinte depoimento:

V. - [...] para controlar, no Kumarumã, eles foram buscar um pai de santo.

Artionka - Onde foram buscar esse pai de santo?!

V. - Em Macapá [a capital do estado do Amapá]. Ele veio, fez um trabalho e falou:

"vai acalmar aqui nessa comunidade, mas as outras vão ficar descobertas". Aí depois deu no Manga [aldeia karipuna], entrava nos alunos dentro da escola que saía só uma gritaria, foi um terror. Eu fiquei muito preocupado, era uma correria na rua, era muita gente, atacou muitos... só jovens. [...] o pai de santo falou o seguinte: "essa coisa aí não é para o pajé [o xamã indígena]". Na nossa cultura [indígena] a gente trabalha com outro tipo de coisa, com as ervas. "O que tá acontecendo é coisa de espírito", disse o pai de santo. Foi impressionante quando ele chegou no Manga, a menina tava quase morrendo, ele olhou assim, falou, "Sai, espírito! Esse corpo não te pertence!", ${ }^{35}$ a menina só fez levantar, saiu tudinho (Karipuna, aldeia karipuna de Santa Isabel, 2013).

Mas se essas linguagens não se repelem terminantemente umas às outras, é importante destacar que os seres espirituais mobilizados nas narrativas são qualificados de maneiras desiguais. Em primeiro lugar, nota-se que os "espíritos" que enlouquecem os jovens são todos vistos como danosos, mas não são valorados da mesma forma pelos interlocutores deste trabalho. Isto remete certamente a distintas histórias de vida - por exemplo, algumas 
pessoas com as quais conversei são professoras e professores, têm, portanto, um contato mais intenso com os não indígenas. Mas essa diferença na concepção dos seres que se apossam dos jovens me parece estar vinculada a modos diversos de relação com o cristianismo. ${ }^{35}$

Para os interlocutores evangélicos palikur - independente da idade, do sexo e do tipo de inserção no mundo dos brancos - imersos em uma sociabilidade que, desde a chegada da religião evangélica, relegou o mundo dos espíritos xamanísticos a um plano marginal, os seres que atacam os jovens na crise são descritos como essencialmente "maus". Eles seriam expressões do demônio, as quais, segundo os mais velhos, ganham espaço pelo afastamento dos jovens "do evangelho", ou seja, pela falta de leitura da Bíblia, pela falta de atenção às pregações dos pastores e por sua fixação e perseguição do estado extático.

Para os católicos karipuna com quem conversei, que em suas aldeias praticam os rituais xamanísticos em paralelo aos rituais católicos, a culpa de estarem sendo afligidos por essa epidemia de ataques espirituais também recai no comportamento das pessoas. Mas aqui o que é visto como mau comportamento seria um afastamento e um desrespeito em relação a práticas consideradas como parte dos "costumes tradicionais", o que faria com que os espíritos dessem vazão a um sentimento de vingança. Para os interlocutores karipuna, ao contrário dos palikur, estes espíritos não carregariam uma malignidade intrínseca, como a do diabo.

Cito duas narrativas nas quais esta diferença se apresenta; a primeira é de um palikur e a segunda é de um karipuna:

M. - [...] lá, quando ataca uma pessoa, moça ou rapaz, eles gritam, "Olha! Satanás! Me segura! Me acode! Agora eu não vou mais com Deus". [...] Essa crise aconteceu... Como ainda agora tava dizendo, a gente não tá seguindo direito o evangelho, aí esse espírito mau pega, ataca a pessoa (Palikur, aldeia karipuna de Santa Isabel, 2013).

V. - [...] a pajé falou que a gente tava esquecendo muito a cultura da gente, as pessoas não estavam mais respeitando o ritual da gente, achavam que era brincadeira uma coisa que é sagrada... O rapaz fez a roça dele, lá no kumarumã, onde era o cemitério, onde tem urnas funerárias. Alegaram que era um espírito de um pajé muito antigo que estava entrando nas pessoas e se vingando porque elas tinham feito roça onde tem um cemitério sagrado, né? Dos antigos (Karipuna, aldeia karipuna de Santa Isabel, 2013). 
Reforçando a diferença em relação a quem a crise mobiliza, esse mesmo interlocutor karipuna descreve os "espíritos" presentes na crise como figuras heterogêneas: um, parece uma pessoa muito grande, uma espécie de gigante; outro, um homem negro e forte; outros ainda, parecem bichos ou seres fantásticos. E quando estas figuras se apossam das pessoas, elas passam a expressar as afecções do Ser que as possuiu:

V. - Fiquei muito preocupado quando deu no rapaz... Eu não tava com medo, tava tranquilo, apareceu nele assim como se fossem duas presas, como se fosse um vampiro, e o menino ficou com tanta força! (Karipuna, aldeia de Santa Isabel, 2013).

No caso palikur, a religião evangélica parece ter reduzido uma miríade de sujeitos à feição unívoca do diabo. Tais seres, que não são simples versões do Diabo, habitam usualmente o Pahakap, o "outro mundo", um mundo que existe em paralelo e é concomitante ao mundo no qual vivem os humanos, estando localizado simultaneamente nos planos celeste, subterrestre e subaquático. A religiosidade cristã penetrou de modo proposital nesse plano, um domínio já eminentemente transformacional.

O fato de a crise ter se alastrado com um tipo semelhante de performance e ser, de um modo geral, objeto de preocupação para as diferentes populações da região, além de descrever um "fluxo transformacional universal" (vide supra), leva a pensar que deve haver uma espécie de gramática comum que estrutura a língua franca do suprassensível evocada aqui. Esta gramática pode estar em um tal nível inconsciente que seria difícil localizar exatamente em qual plano ela se dá. Pela leitura do contexto do baixo Oiapoque, o princípio xamanístico de permeabilidade que caracteriza os diferentes mundos do $\operatorname{cosmos}_{1}{ }^{36}$ assim como o fato de o xamanismo ser parte deste mundo transformacional que se cria e se altera na (e em) relação parecem-me ser aspectos cruciais no processo de reunião das distintas formas de religiosidade cristã e das práticas ritualísticas indígenas.

\section{Relação, transformação}

Depois dessa exposição, é evidente que não seria apropriado discorrer sobre a crise como se fosse um evento formado por (e provocador de) situações ímpares, como se os indígenas da região do baixo rio Oiapoque tivessem ido "da tradição ao cristianismo", usando as palavras de Barker ao falar da atenção que se deve ter em relação ao que ele chama de "conversões secundárias" (Barker, J. 2012:78). ${ }^{37}$ Acrescento, tomando liberdades com a 
imagem criada por Barker, que a vida social pode ser vista como uma série de "conversões secundárias", tendo também em mente a seguinte asserção de Strathern:

O estudo das relações sociais antecipa qualquer ilusão de primeiro contato: não se encontra ninguém "pela primeira vez", pois nunca se viveu na ausência de relacionamentos. A interação é possível na premissa minimalista de que as pessoas (como os conceitos) são inevitavelmente vividas e percebidas como versões de outras pessoas - elas estão sempre, nesse sentido, já em um relacionamento [...] (1995a:164 - tradução minha).

A história dos povos indígenas nesta região mostra que as diferentes religiões cristãs se constituíram num processo formado por múltiplas camadas de "cristianismos". A "tradição" aqui é, portanto, já uma transformação. Este fato reforça a posição de extinção da polaridade mudança/continuidade ${ }^{38}$ que reivindico neste texto. Não fosse por tudo já dito, ela não é representativa para o caso analisado, porque nele entende-se que na mudança há continuidade e vice-versa.

Neste terreno de múltiplas transformações, há um lugar nas socialidades nativas que o cristianismo privilegia em sua ação de proselitismo: é fácil deduzir que se trata do xamanismo. É sobre ele e sobre "seu agente prático", ${ }^{39}$ o xamã, entendidos como o lugar do religioso e da "tradição cultural" nas sociedades indígenas, que se concentram, de maneira geral, os esforços de conversão, sobretudo das chamadas missões transculturais, muito frequentes na Amazônia e atuantes entre os povos do baixo rio Oiapoque. ${ }^{40}$

Não é à toa que os missionários elegem, de partida, o xamã como o principal interlocutor. Nos estudos antropológicos de populações indígenas, ele é considerado como uma espécie de tradutor por ser o único habilitado a transitar pelos diferentes planos do cosmos e voltar vivo para contar o que viu nas outras dimensões. A experiência que forma o xamã transforma-o em Outro, e o reconstitui. A iniciação xamanística de Davi Kopenawa é uma explicação concreta das metamorfoses sofridas por este tipo de viajante transcósmico. Quando enfim conseguiu "imitar" as vozes dos espíritos e tornou-se um xamã completo, o corpo de Kopenawa havia sido sobejamente "trinchado" e reconstruído pelos espíritos xapiri. Tomo apenas o que ocorreu à sua língua como imagem de todo o processo:

[...] Pegaram-na para refazê-la, para torná-la bela e capaz de proferir palavras sábias. Lavaram-na, lixaram-na e alisaram-na, para poder impregná-la com suas melodias [...]. Tornaram-na outra, luminosa e brilhante como se emitisse raios. Foi assim que os xapiri prepararam minha língua. Fizeram dela uma língua 
leve e afinada. Tornaram-na flexível e ágil. Transformaram-na numa língua de árvore de cantos, uma verdadeira língua de espírito. Foi então que eu pude enfim imitar suas vozes e responder às suas palavras com cantos direitos e claros (D. Kopenawa \& B. Albert 2015:154-55).

Aquele ou aquela que passa por isto e se transforma em xamã pode, enfim, fornecer entendimento entre linguagens diferentes. Entendimento que é, de acordo com Carneiro da Cunha, sempre parcial e produzido por meio de uma "suspensão da linguagem ordinária", a qual está presente nos cantos xamanísticos. Se, para conhecer os "outros mundos" é preciso uma perspectiva ampliada (como é a do xamã), estes "outros mundos", no entanto, não se deixam apreender por inteiro (Carneiro da Cunha 1998:13). Aqui me parece também valer a lógica aplicada aos mitos por Lévi-Strauss, para quem, em sua reprodução, a fórmula traduttore, traditore tende praticamente a zero (Claude Lévi-Strauss 1958:232).

Para os missionários transculturais trata-se de brigar num mesmo campo semântico, o do conhecimento que extrapola o mundano. Desse modo, a atitude inicial de busca do aprendizado e da aceitação das cosmologias nativas, com o tempo, demonstra ter o objetivo estratégico de apropriar-se de suas noções para posteriormente subvertê-las e negá-las - veja-se a interpretação palikur sobre o estatuto dos espíritos da crise. O resultado disso é que o movimento de tradução, que se dá no processo de cristianização, também produz uma "suspensão da linguagem ordinária" que vai aos poucos criando um novo campo de significação, alimentado por um conhecimento parcial sobre a socialidade e a cosmologia nativas.

Com isso, o que o cristianismo produz é uma espécie de tradução original, o que pareceria uma heresia se tomarmos "tradução" como um processo simples de transposição de sentidos de uma língua a outra, mas que faz sentido se a concebermos como uma "tradução criativa", da forma proposta por Carneiro da Cunha para explicar como entende o lugar de "tradutor" do xamã:

A síntese original, o sistema sintagmático no qual há necessidade de aderência entre o som e o sentido, no qual o som e o sentido se ajustam sem falhas como o fruto e sua pele (Benjamin 1968), tudo isso se dissolveu. O que se trata de (re) construir é uma síntese original, uma nova maneira de pôr em relação níveis, códigos, pô-los em ressonância, em correspondência, de modo que esse mundo novo ganhe a consistência desejada para que se torne evidente. Em suma, que adquira um sentido, pois o sentido é, ao fim e ao cabo, a percepção de relações (Carneiro da Cunha 1998:14 - grifo meu). 
A "percepção de relações" que permite o ato da tradução (xamanística e missionária) também surge nas narrativas indígenas sobre a crise como o principal elemento explicativo. As conexões que se estabelecem (entre jovens, brancos, espíritos, demônios) ou que deixam de se estabelecer (entre adultos e jovens) na crise abrem um campo de entendimento capaz de "dar sentido", mais de um sentido, ao fenômeno - pois se, por exemplo, para os Palikur, a crise é um rebote do demônio sobre si, para os Karipuna, não há demônio em jogo e o rebote se dá pelos espíritos xamanísticos. Os significados variam de acordo com as redes de relações em que estão imersos os sujeitos envolvidos na crise.

Há, a despeito das diferenças, um sentido que aproxima as explicações karipuna e palikur. Este sentido está relacionado ao lugar de produção e definição de pessoa dado pela alteridade numa metafísica que concebe a transformação como constituinte do Ser. ${ }^{41}$ Isto, como o fenômeno apresentado mostra, vale quando Outrem é Deus, o Diabo ou os espíritos xamanísticos, todos eles igualmente constituídos como "pessoas compósitas". Este quadro só pode ser compreendido se concebermos que a condição do/de Ser é inerentemente transformacional. Assim, a metáfora inicial usada neste texto torna-se persuasiva, pois as capas não só podem passar do veludo ao algodão, do algodão à seda, mas em realidade serão sempre de tecidos mesclados.

Recebido em 10 de agosto de 2016

Aprovado em 11 de julho de 2017

Artionka Capiberibe é professora do Departamento de Antropologia da Unicamp. E-mail: <artionka@g.unicamp.br> 


\section{Notas}

* Este texto é devedor de um diálogo de anos com algumas pessoas, em especial com Aparecida Vilaça e Ronaldo de Almeida. Suas sugestões, feitas em diferentes momentos, estão em grande medida incorporadas aqui. Partes deste trabalho também tiveram o aporte de Lux Vidal e Robin Wright, a quem sou reconhecida. Agradeço, igualmente, as observações dos/das pareceristas, que me permitiram desenvolver (e esclarecer) alguns pontos insuficientemente explorados. A realização do trabalho beneficiou-se das seguintes fontes de financiamento: projeto Ford/Cebrap "Effects of intellectual and cultural rights protection on traditional people and traditional knowledge. Case studies in Brazil" (maio de 2013); PPGAS-Museu Nacional/UFRJ e projeto NUTI-PRONEX "Transformações indígenas: os regimes de subjetivação ameríndios à prova da história" (2003); bolsa de doutorado Capes (2004-2008) e bolsa PDEE/Capes para estágio de doutorado na França (2006-2007). Ressalvo, finalmente, que as eventuais fragilidades presentes aqui se devem somente a mim.

1 A despeito do ganho teórico (e político) que representa a introdução da história na análise estrutural de processos de mudança cultural feita por Sahlins (1985), a dicotomia entre um estado que permanece, via agência indígena, e a transformação que decorre do processo histórico não é enfrentada. Permanece o jogo da balança, quando o que as etnografias mostram são realidades mais compósitas.

2 Após encerrar a escrita deste texto, tomei contato com as publicações e os discursos da socióloga aymara boliviana Silvia Rivera Cusicanqui. Sua proposta de pensamento descolonizado, centrada no conceito aymara $c h$ 'ixi e numa metodologia que se vale da imagem visual como meio de produção de pensamento crítico é inspiradora. A ideia do ch'ixi, como o lugar daquilo que simultaneamente é e não é, e a imagem das cores (veja-se a epígrafe) que Cusicanqui $(2010,2011)$ mobiliza vieram ao encontro da alegoria machadiana do manto, tornando mais nítida a ideia por trás da metáfora que proponho.

3 Só para o contexto americanista há, pelo menos, quatro coletâneas dedicadas a este tema: R. Wright (1999, 2004); P. Montero (2006); A. Vilaça e R. Wright (2009). Isto sem contar os trabalhos monográficos que, sendo em número considerável, citar alguns seria incorrer em omissões.

4 Vejam-se as introduções de R. Hefner (1993) e F. Cannell (2006). Para o contexto indígena brasileiro, o balanço sobre estudos de religião de R. de Almeida (2010).

5 Esta plasticidade é objeto de discussão tanto nas Igrejas de missão como nos estudos antropológicos. Como coloca F. Cannell (2006:25-30), a questão central envolve pensar até que ponto pode ir o cristianismo sem se desfigurar.

6 O termo sociocosmologia é empregado aqui no sentido cunhado por Viveiros de Castro a partir da etnografia sobre os Araweté, na qual ele demonstra a existência de uma tal imbricação entre a sociologia e a cosmologia indígenas que tornaria falso pensar estes dois domínios em separado (Viveiros de Castro 1986). 
7 Embora haja um acúmulo de etnografias que mostrem o ato contínuo e perpétuo de transformação pensado e exercido pelas populações indígenas a respeito de tudo que lhes diz respeito, a antropologia parece não conseguir parar de exorcizar o fantasma da aculturação, que reencarna a cada vez que se reedita a dicotomia continuidade/mudança. A ideia de transformação, de base levistraussiana, tão bem explorada etnograficamente por Peter Gow (1991), deveria permitir à disciplina livrar-se deste fardo.

8 É interessante notar os significados que a "transformação" alcança. João Pina-Cabral faz uso das ideias de "fixity" e "recurrence" para compreender a permanência no catolicismo rural europeu de crenças e práticas religiosas, entendidas como "superstição" e "atraso" por interpretações que privilegiam a noção de progresso (Pina-Cabral 1992). O que se nota é um caráter permanentemente transformacional, mesmo que tais transformações se deem a partir da recorrência de algo que estava lá, como no caso analisado por Pina-Cabral, e não da inserção de algo novo, como é o caso das religiões cristãs em contextos indígenas.

9 O uso do termo "relação" tem em conta a proposição de Marilyn Strathern, que se aplica a qualquer forma de conexão e ativa vários sentidos às conexões que designa. Estas são complexas, porque os elementos em conexão sempre convocam outras entidades diferentes deles próprios, ou seja, “[...] one does not only see relations between things but things as relations [...]" (Strathern 1995a:19).

10 As práticas conhecidas como "couvade" (uma redefinição para o contexto ameríndio deste termo, que faz parte da história da antropologia, está em P. Rivière 1974) são um bom exemplo deste significado sociocosmológico das relações. Elas constituem a forma particular de um fenômeno mais geral que diz respeito à composição da pessoa em um corpo físico e uma espécie de corporeidade incorpórea, algo que vem sendo chamado na etnologia indígena ora de duplo, ora de sopro vital, ora de alma. Esta constituição do Ser se apresenta, em geral, como um processo em construção, o que permite uma disputa interespecífica pela pessoa. É por isso que os recém-nascidos são objeto de tantos cuidados, como, por exemplo, os que envolvem a fabricação do corpo da criança. Entre os Wari' (povo indígena localizado em Rondônia, Amazônia brasileira), para os quais o bebê é "construído" durante a gravidez pela injeção de sêmen na mãe - ou seja, por um excesso de proximidade entre os humanos que estão produzindo o novo ser - após o nascimento do bebê, o pai e a mãe devem seguir prescrições alimentares, o pai deve ficar recluso e, além disso, o xamã precisa se manter em negociações constantes com os outros seres que povoam o mundo para tentar garantir que eles, que se veem como humanos, não se apropriem do pequeno recém-nascido e o transformem num ser de natureza (ou corpo) semelhante ao deles (Vilaça 2002). Cf. também o artigo seminal de Seeger, DaMatta e Viveiros de Castro (1979).

11 Este debate tem como principais expoentes o "Animismo", de Philippe Descola (2005), e o "perspectivismo", de Viveiros de Castro (2002) e Tânia Stolze Lima (1996). Nos anos 2000, a discussão extrapolou as fronteiras da etnologia indígena sul-americana ensejando o que veio a ser chamado de "virada ontológica" e gerando uma massa de debates sobre o tema. 
12 Esta é uma questão posta pelo projeto "Nuti-Pronex"/Museu Nacional-UFRJ (E. Viveiros de Castro \& C. Fausto 2003), do qual fiz parte, e que tem me acompanhado desde então.

13 Esse território, localizado ao norte da foz do rio Amazonas, foi disputado por Portugal com outros países europeus, mas sobretudo com a França, numa contenda diplomática que se estendeu por dois séculos, de 1700 a 1900, atravessando a história do país, do Brasil Colônia à instituição da República, em 1889. Onze anos depois, em 1900, o país ganhou a disputa diplomática e a fronteira com a França foi estabelecida no talvegue do rio Oiapoque, cerca de 300 milhas acima da foz do Amazonas.

14 A começar pelos próprios Palikur que surgem nas fontes e na memória oral divididos em vários subgrupos falantes de línguas distintas e espalhados por espaços geográficos diferentes, sendo possível contabilizar mais de 20 desses subgrupos. Cf. C. Nimuendaju (2009), Françoise Grenand e Pierre Grenand (1987), Alan Passes (2004).

15 As Terras Indígenas (T.Is.) da região do Oiapoque são Uaçá I e II, Juminã e Galibi, todas demarcadas e homologadas desde os anos 1990. Juntas, somam pouco mais de 500.000 ha.

16 Os dados populacionais provêm da Enciclopédia dos Povos Indígenas no Brasil. Disponíveis em <https://pib.socioambiental.org/pt/c/quadro-geral >. Acesso em 08/04/2017.

17 A cidade de Oiapoque é um pequeno centro urbanizado que reúne uma população de cerca de 25.000 pessoas, população estimada para o ano de 2016 segundo o Instituto Brasileiro de Geografia e Estatística (IBGE) a partir do censo de 2010. Dados disponíveis em: < http://cidades.ibge.gov.br/xtras/ perfil. php?lang $=\& \operatorname{codmun}=160050>$. Acesso em 08/04/2017. A população total da Guiana francesa é de cerca de 250.000 pessoas, a cidade de Saint-Georges de L'Oyapoc tem uma população legal (há uma taxa elevada de imigração ilegal, por isso os dados de população são sempre estimativas) de cerca de 4.000 pessoas. Dados disponíveis em: <https://www.insee.fr/fr/statistiques/2540209> <https://www.insee.fr/fr/ statistiques/2534314?geo=COM-97308\# consulter $>$. Acesso em 08/04/2017. Estes dados são de 2014 do recenseamento realizado pelo Institut National de la Statistique et des Études Économiques (INSEE).

18 "Desobriga" é um termo da Igreja Católica aplicado a visitas pastorais feitas a lugares sem muito acesso com a finalidade de promover a catequese e ministrar sacramentos.

19 A teologia da inculturação significa uma mudança de orientação na ação missionária católica decorrente da autocrítica de seu papel no processo colonizador. As teses da inculturação propõem uma inversão no processo de conversão, abrindo mão do proselitismo religioso direto por entender haver nas culturas locais valores cristãos fundamentais, tais como: amor, fraternidade, solidariedade, justiça etc. (R. Almeida 2006:283). Sobre a inculturação na atuação do CIMI, ver também M. Rufino (2013).

20 Embora minha pesquisa de campo seja centrada nos Palikur, fui algumas vezes a aldeias galibi-marworno, karipuna e na aldeia galibi-kali'na, assim como mantenho contato frequente com pessoas dessas populações na cidade de Oiapoque. 
As informações aqui passadas são dados de observação direta, aliados à bibliografia dos antropólogos com pesquisas de campo na região. As principais referências são: Lux Vidal (1999, 2000), Antonella Tassinari (2003), Laércio F. Dias (2005) e Ugo Maia Andrade (2007).

21 No quadro de missões religiosas presentes nas áreas indígenas no Brasil, Ronaldo de Almeida aponta a presença maciça de igrejas de tradição fundamentalista, nas quais estão evidentes estes elementos, senão todos, ao menos mais de um deles. Diz o autor: "Em resumo, a tradição fundamentalista envolve um conjunto de características que remonta à Reforma Protestante, mais Lutero do que Calvino; ao metodismo na Inglaterra do século XVIII; aos "avivamentos" na Inglaterra, também, no fim do XVIII e nos Estados Unidos, em meados do XIX, principalmente entre batistas, e boa parte dos presbiterianos e metodistas; além de embasar o nascente pentecostalismo no início do século XX" (2001:31).

22 A literatura sobre povos da Amazônia registra a vasta extensão deste tipo de concepção sobre sonho, veja-se, por exemplo: A. Barcelos Neto (2002), Anne-Gaël Bilhaut (2011) e o intenso trabalho sobre xamanismo Yagua de Jean-Pierre Chaumeil (2000). No contexto australiano, Barbara Glowczewski (2004) mostra, por meio de narrativas aborígenes, a ação que os sonhos têm, estando diretamente relacionados à produção e à reprodução destes povos.

23 Para uma narrativa descrevendo esta experiência, ver Capiberibe (2007:208-9).

24 Os Palikur concebem a conversão religiosa evangélica como o início de uma vida que dizem ser "civilizada". Dois exemplos potentes deste tipo de concepção podem ser vistos nos trabalhos de Peter Gow $(1991,2006)$, entre os Piro, e de Oiara Bonilla (2007, 2009), entre os Paumari.

25 Atualmente há sete sedes de Igrejas Assembleia de Deus entre os Palikur, quatro nas aldeias do rio Urukauá, e três em bairros palikur do lado francês.

26 Em trabalho de campo realizado em 2013, observei alguns dos fatos ocorridos entre os Palikur. Sobre os eventos que se deram entre os Karipuna e Galibi-Marworno obtive apenas relatos.

27 Utilizo o termo socialidade no sentido estabelecido por Strathern (2006:40), que o opõe ao termo sociabilidade. Socialidade implica relações sociais desvencilhadas de uma ideia de sociedade como coletividade, ou seja, prescindindo de "uma experiência de comunidade, de empatia" (1999:169), que são ideias presentes no significado de sociabilidade.

28 Manterei o anonimato dos meus interlocutores e interlocutoras, pois este tema é delicado e continua causando mal-estar na região, restringindo-me (para permitir que possam ser diferenciados e diferenciadas) a indicar uma letra como marcador individualizado, a etnia, a aldeia e a data em que foi tomada a narrativa.

29 Utilizo o termo "branco" com o sentido genérico de não indígena. 
30 Este entendimento é bastante difundido, hoje, pelos intelectuais indígenas. Davi Kopenawa é certamente o porta-voz mais conhecido do caráter deletério de um contato muito estreito com as "coisas dos brancos" (Kopenawa \& Albert 2015).

31 Esta concepção vem sendo explorada à exaustão, desde o final dos anos 1970, com a virada da etnologia ameríndia na teoria antropológica. Para uma ideia sobre as diretrizes iniciais desse processo, ver J. Overing (1977) e Seeger, DaMatta e Viveiros de Castro (1979).

32 Seria avançar muito além do que se pretende neste trabalho, mas faço uso da expressão "objetos-sujeitos" para explicitar que tais coisas são também capazes de criar sentidos, indo ao encontro da proposta de Amiria Henare, Martin Holbraad e Sari Wastell (que não endosso totalmente, mas que põe questões interessantes para pensar) de que as "coisas", e nossa experiência com elas, são conceituais, ou seja, pode-se encarar com densidade as "coisas" (os objetos) como pessoas ou sujeitos, o que, para o caso que analiso, reforça o argumento de que relações impõem transformações, mesmo aquelas relações que se dão com objetos-sujeitos.

33 A expressão "as palavras" significa ao mesmo tempo a exegese bíblica do Novo Testamento e a pregação do pastor. O trabalho de 12 anos em campo do Summer Institute of Linguistics (SIL) resultou na tradução para o parikwaki do Novo Testamento e de partes do Velho Testamento, que constituem a Bíblia palikur Uhokri Gannasan (A Palavra de Deus), no entanto, não são muitas as pessoas que se valem dessa Bíblia nos cultos. Diga-se ainda, que as Igrejas evangélicas pentecostais, de modo geral, têm uma "reduzida presença explícita de uma teologia no sentido mais estrito" (Velho 1997:144); o que se passa é uma "desteologização", acompanhada da ênfase no "Espírito" (1997:144), um esvaziamento da clássica racionalidade weberiana mais associada a uma moral e a uma ética comportamental do que à sobrevalorização da emoção.

34 Esta é uma frase típica das igrejas pentecostais durante o exorcismo de demônios, mas aqui aparece na boca de um pai de santo, curiosamente alvo dos exorcismos destas igrejas, sobretudo da Igreja Universal do Reino de Deus. O trânsito de expressões parece apoiar a ideia, aqui avançada, de um compartilhamento de sentidos que se dá no âmbito suprassensível.

35 Como advertida por um/a parecerista, posso estar, nesta caracterização, incorrendo em uma "certa essencialização dos grupos do ponto de vista étnico". Em relação aos Palikur, a generalização tem por base minha pesquisa etnográfica, assim como o cotejamento de meus dados com o de outros pesquisadores, como Alan Passes (1998, 2002, 2003), Lesley Green (2005), Lesley Green e David Green (2013) e Álvaro Mussolino (2006). Em relação aos Karipuna, valho-me aqui da detalhada etnografia de Antonella Tassinari, na qual ela demonstra que os rituais e as práticas xamanísticas convivem em paralelo com uma religiosidade católica assentada nas festas aos Santos (2003). Também me apoio nos trabalhos comparativos sobre os povos desta região produzidos por Lux Vidal (1999, 2000, 2001).

36 É justamente essa conexão entre mundos que faz com que o xamã Davi 
Kopenawa (Kopenawa \& Albert 2015) alerte para o caráter escatológico dos abusos cometidos contra o meio ambiente; destruir o mundo terreno implica destruir todos os outros mundos.

37 O artigo faz uma crítica a leituras antropológicas sobre o cristianismo que desconsideram os processos históricos vividos pelas populações nativas. Barker fala de um lugar privilegiado, pois acompanha, no longo termo, o tema do cristianismo na Melanésia (Barker 1992, 1993).

38 Para a mais recente versão deste debate, cf. as seções especiais "Comparison made radical: Dumont's anthropology of value today" e "The anthropology of personhood, redux: Views from Christianity", da HAU de 2015, em especial os artigos de Robbins, Vilaça e Mosko.

39 Transliteração de uma expressão de Almeida (2006:289).

40 As missões transculturais levam a mensagem cristã e se fazem entender nos idiomas e nas culturas nativas. Para elas, Deus é entendido como valor autóctone e está presente no universo cosmológico indígena, bastando para alcançá-lo traduzir este universo para as categorias cristãs (Almeida 2006).

41 Esta ideia me foi suscitada a partir dos diálogos estabelecidos no projeto "Nuti-Pronex" (E. Viveiros de Castro \& C. Fausto 2003), relacionada à noção de que "[...] Não há alteridade sem alteração. Abstraída da potência de alteração de que procede, a alteridade se congela em uma 'relação' meramente formal, e frequentemente degenera em uma taxonomia de oposições diacríticas entre posições constituídas" (2003:24). 


\section{Referências bibliográficas}

ALMEIDA, Ronaldo de. 2001. Traduções do fundamentalismo evangélico. Ph.D. Dissertation, Universidade de São Paulo, USP.

. 2006. "Tradução e mediação: missões transculturais entre grupos indígenas". In: P. Montero (org.), Deus na aldeia: missionários, índios e mediação cultural. Rio de Janeiro: Editora Globo. pp. 277-304.

. 2010. "Religião em transição". In: C. B. Martins \& L. F. Dias Duarte (eds.), Horizontes das ciências sociais no Brasil: antropologia. São Paulo: Anpocs/Instituto Ciência Hoje/Ed. Barcarolla e Discurso Editorial. pp. 367-405.

ANDRADE, Ugo Maia. 2007. O real que não é visto. Xamanismo e relação no baixo Oiapoque. Ph.D. Dissertation, Universidade de São Paulo, USP.

BARCELOS NETO, Aristóteles. 2002. $A$ arte dos sonhos: uma iconografia ameríndia. Lisboa: Museu Nacional de Etnologia/Assírio \& Alvim.

BARKER, John. 1992. "Christianity in Western Melanesian ethnography". In: J. G. Carrier (ed.), History and tradition in Melanesian anthropology. Berkeley: UC Press. pp. 144-71.

. 1993. "'We are Eklesia': conversion in Uaiku, Papua New Guinea". In: R. W. Hefner (ed.), Conversion to Christianity. Historical and anthropological perspectives on a great transformation. Berkeley: University of California Press. pp. 199-230.

. 2012. "Secondary conversion and the anthropology of Christianity in Melanesia". Archives des Sciences Sociales des Religions, 157:67-87, Janvier-Mars.

BILHAUT, Anne-Gaël. 2011. Des nuits et des rêves: construire le monde Zápara en Huate-Amazonie. Nanterre: Société d'Etnologie.
BONILLA, Oiara Lydie. 2007. Des proies si désirables: soumission et prédation pour les Paumari d'Amazonie brésilienne. Ph.D. Dissertation, École des Hautes Études en Sciences Sociales Anthropologie Sociale et Ethnologie. . 2009. "The skin of history: paumari perspectives on conversion and transformation". In: A. Vilaça \& R. Wright (eds.), Native christians. Modes and effects of Christianity among indigenous peoples of the Americas. Farnham and Burlington VT: Ashgate Publishing. pp. 127-146.

CAPIBERIBE, Artionka. 2007. Batismo de fogo: os Palikur e o Cristianismo. São Paulo: Annablume Editora. . 2009. Nas duas margens do rio: alteridade e transformações entre os Palikur na fronteira Brasil/ Guiana francesa. Ph.D. Dissertation, Museu Nacional/Universidade Federal do Rio de Janeiro (UFRJ).

. 2014. "Não cutuque a cultura com vara curta: os Palikur e o projeto 'Ponte entre Povos'". In: M. Carneiro da Cunha e P. Cesarino (orgs.), Políticas culturais e povos indígenas. São Paulo: Cultura Acadêmica Ed. pp. 165-95.

CANNELL, Fenella. 2006. "Introduction: the anthropology of Christianity". In: F. Cannell (ed.), The anthropology of Christianity. Durham \& London: Duke University Press. pp. 1-50.

CARNEIRO DA CUNHA, Manuela. 1998. "Pontos de vista sobre a Floresta Amazônica". Mana, 4(1):7-22.

CHAUMEIL, Jean-Pierre. 2000. Voir, savoir, pouvoir: le chamanisme chez les Yagua de l'Amazonie péruvienne. Paris: Georg Éditeur.

CUSICANQUI, Silvia Rivera. 2010. Ch'ixinakax utxiwa: Una reflexión sobre prácticas y discursos descolonizadores. Buenos Aires: Tinta Limón. 
2011. De Chuequistas y Overlockas: una discusión entorno a los talleres textilles. Buenos Aires: Tinta Limón.

DESCOLA, Philippe. 2005. Par-delà nature et culture. Paris: Gallimard.

DIAS, Laércio F. 2005. O bem beber e a embriaguez reprovável segundo os povos indígenas do Uaçá. Ph.D. Dissertation, Universidade de São Paulo, USP.

FAUQUE, Elzéar. 1993. "Lettre au P. de la Neuville, Ouyapoc, le 2 juin 1735" e "Lettre au P. de la Neuville, Ouyapoc, le 20 septembre 1736". In: I. Vissière \& J-L. Vissière (orgs.), Peaux-rouges et robes noires: lettres édifiantes et curieuses des jésuites français en amérique au XVIII ${ }^{e}$ siècle. Paris: Collection Outre-mers aux éditions de la différence. pp. 329-48.

FRESTON, Paul. 1994. "Uma breve história do pentecostalismo brasileiro: a Assembleia de Deus". Religião e Sociedade, 16(3):104-29.

GREEN, Lesley J. F. 2005. "'Ba pi ai?' rethinking the relationship between secularism and professionalism in anthropological fieldwork". Anthropology Southern Africa, 28(3\&4):91-8.

GREEN, Lesley; GREEN, David. 2013. Knowing the day, knowing the world: Engaging Amerindian thought in Public Archaeology. Tucson: Arizona University Press.

GLOWCZEWSKI, Barbara. 2004. Rêves en colère: alliances aborigènes dans le Nord-Ouest Australien. Paris: Plon/ Terre Humaine Poche.

GOW, Peter. 1991. Of mixed blood: kinship and history in Peruvian Amazonia. Oxford: Clarendon Press.

. 2006. "Forgetting conversion: The Summer Institute of Linguistics Mission in the Piro lived world". In: F. Cannell (ed.), The anthropology of Christianity. Durham/London: Duke University Press. pp. 211-39.
GRENAND, Françoise; GRENAND, Pierre. 1987. "La côte d'Amapá, de la bouche de l'Amazone a la baie d'Oiapoque, à travers la tradition orale Palikur". Boletim do Museu Paraense Emílio Goeldi, 3(1):1-77.

HEFNER, Robert W. 1993. "World building and the rationality of conversion". In: R.W. Hefner (ed.), Conversion to Christianity: historical and anthropological perspectives on a great transformation. Berkeley: University of California Press. pp. 3-44.

HENARE, Amoria; HOLBRAAD, Martin; WASTELL, Sari. 2007. "Introduction: thinking through things". In: A. Henare; M. Holbraad; S. Wastell (eds.), Thinking through things: theorising artefacts ethnographically. New York/ London: Routledge. pp. 1-31.

HURAULT, Jean-Marcel. 1972. Français et indiens en Guyane 1604-1972. Paris: Union Générale d'Éditions.

KOPENAWA, Davi; ALBERT, Bruce. 2015. A queda do céu: palavras de um xamã yanomami. São Paulo: Companhia das Letras.

LÉVI-STRAUSS, Claude. 1958. "La structure des mythes". In: __. (org.), Anthropologie structurale. Paris: Plon. pp. 227-56.

. 1976 [1962]. "A ciência do concreto". In: ___. (org.), O Pensamento Selvagem. São Paulo: Ed. Nacional. pp. 19-55.

LIMA, Tânia Stolze. 1996. "O dois e seu múltiplo: reflexões sobre o perspectivismo em uma cosmologia tupi". Mana, 2(2):21-48.

MONTERO, Paula (org.). 2006. Deus na aldeia: missionários, índios e mediação cultural. Rio de Janeiro: Editora Globo.

MOSKO, Mark S. 2015. "Unbecoming individuals: the partible character of the christian person". HAU: Journal of Ethnographic Theory, 5(1):36193. Disponível em: http://dx.doi. org/10.14318/hau5.1.017. Acesso em 20/02/2016. 
MUSSOLINO, Álvaro. 2006. Migração, identidade e cidadania palikur na fronteira do Oiapoque e litoral sudeste da Guiana francesa. Ph.D. Dissertation, Universidade de Brasília, CEPPAC/UnB.

NIMUENDAJU, Curt. 2009 [1926]. Les indiens palikur et leurs voisins. P. Grenand (intro., ed. e notas). Orléans: Presses Universitaires d'Orléans/ CTHS.

OVERING, Joanna. 1977. "Comments (Symposium 'Social time and social space in lowland South American societies')". Actes du XLII Congrès International des Américanistes, II:387-94.

. 1991. "A estética da produção: o senso de comunidade entre os Cubeo e os Piaroa". Revista de Antropologia, 34:7-33.

PASSES, Alan. 1998. The hearer, the hunter, and the agouti head: aspects of intercommunication and conviviality among the Parikwene (Palikur) of French Guiana. Ph.D. Dissertation, University of St. Andrews.

. 2002. "Both omphals and margin: on how the Pa'ikwené (Palikur) see themselves to be at the center and on the edge at the same time". In: J. D. Hill \& F. Santos-Granero (eds.), Comparative Arawakan histories: rethinking language family and culture area in Amazonia. Urbana e Chicago: University of Illinois Press. pp. 171-195.

. 2003. "You are what you speak, or are you? Identity, language, sociocultural change, and the Pa'ikwené (Palikur)". Estudios Latinoamericanos, 23:91-108.

. 2004. "The gathering of the clans: the making of the Palikur Naoné". Ethnohistory, 51(2):257-291.

PINA-CABRAL, João. 1992. "The gods of the gentles are demons: the problem of pagan survivals in European culture". In: Kirsten Hastrup (ed.), Other histories. London: Routledge. pp. 45-61.

RIVIÈRE, Peter G. 1974. "The couvade: a problem reborn". Man, New Series, 9(3):423-435. Disponível em: 10.2307/2800693. Acesso em 05/10/2014.

ROBBINS, Joel. 2015. "Dumont's hierarchical dynamism: Christianity and individualism revisited". HAU: Journal of Ethnographic Theory, 5(1):173-95. Disponível em: http:// dx.doi.org/10.14318/hau5.1.009. Acesso em 20/02/2016.

RUFINO, Marcos P. 2013. "The Indigenist Missionary Council: a Brazilian experience between culture and faith". In: Sergio Botta (ed.), Manufacturing otherness: missions and indigenous cultures in Latin America. Cambridge: Cambridge Scholars Publishing. pp. 209-28.

SEEGER, Anthony; DAMATTA, Roberto \& VIVEIROS DE CASTRO, Eduardo. 1979. "A construção da pessoa nas sociedades indígenas brasileiras". Boletim do Museu Nacional, 32:2-19.

SAHLINS, Marshall. 1985. Islands of history. Chicago: University of Chicago Press.

STRATHERN, Marilyn. 1992. After nature: English kinship in the late twentieth century. New York: Cambridge University Press. . 1995. The relation: issues in complexity and scale. Cambridge: Prickly Pear Press.

. 1995a. "The nice thing about culture is that everyone has it". In: M. Strathern (ed.), Shifting contexts: transformations in anthropological knowledge. London/New York: Routledge. pp. 153-76. . 1999. "No limite de uma certa linguagem". Mana, 5(2):157-75. . 2006. O gênero da dádiva. Campinas: Editora da Unicamp. 
SUMMER INSTITUTE OF LINGUISTICS. 1982. Uhokri Gannasan: o Novo Testamento na língua Palikúr. Brasília: Livraria Cristã Unida.

TASSINARI, Antonella M. I. 2003. No bom da festa: o processo de construção cultural das famílias karipuna do Amapá. São Paulo: Edusp.

VELHO, Otávio. 1997. "Globalização: antropologia e religião". Mana, 3(1):133-54.

VIDAL, Lux. 1999. "O modelo e a marca, ou o estilo dos 'misturados'. Cosmologia, história e estética entre os povos indígenas do Uaçá". Revista de Antropologia, 42(1 e 2):29-45. . 2000. "Outros viajantes: de Maná ao Oiapoque, a trajetória de uma migração". Revista USP, 46:42-51. . 2001. "Mito, história e cosmologia: as diferentes versões da guerra dos Palikur contra os Galibi, entre os povos indígenas da bacia do Uaçá, Oiapoque, Amapá". Revista de Antropologia, 44(1):117-147.

VILAÇA, Aparecida. 2002. "Making kin out of others in Amazonia". Journal of the Royal Anthropological Institute, 8(2):347-65. . 2015. "Dividualism and individualism in indigenous Christianity: a debate seen from Amazonia". HAU: Journal of Ethnographic Theory, 5(1):197-225. Disponível em: http:// dx.doi.org/10.14318/hau5.1.010. Acesso em 20/02/2016.

VILAÇA, Aparecida \& WRIGHT, Robin (eds.). 2009. Native christians. Mo- des and effects of Christianity among indigenous peoples of the Americas. Farnham and Burlington VT: Ashgate Publishing.

VIVEIROS DE CASTRO, Eduardo. 1986. Araweté, os deuses canibais. Rio de Janeiro: Jorge Zahar Editor/Anpocs. . 2002. "Perspectivismo e multinaturalismo na América indígena". In: A inconstância da alma selvagem - e outros ensaios de antropologia. São Paulo: Cosac \& Naify. pp. 345-99.

. 2012. "'Transformação' na antropologia, transformação da 'antropologia'". Mana [on-line], 18(1):151-171. Disponível em: http://dx.doi.org/10.1590/S010493132012000100006. Acesso em 15/10/2015.

VIVEIROS DE CASTRO, Eduardo \& FAUSTO, Carlos (orgs.). 2003. "Transformações indígenas: os regimes de subjetivação ameríndios à prova da história" (Projeto "Nuti-Pronex"). Rio de Janeiro: PPGAS/ Museu Nacional-UFRJ. Mimeo.

WAGNER, Roy. 2010. A invenção da cultura. São Paulo: Cosac \& Naify.

WRIGHT, Robin (org.). 1999. Transformando os deuses: os múltiplos sentidos da conversão entre os povos indígenas no Brasil. Campinas-SP: Editora da Unicamp. (org.). 2004. Transformando os deuses: Igrejas evangélicas, pentecostais e neopentecostais entre os povos indígenas no Brasil. vol. II. Campinas-SP: Editora da Unicamp. 


\section{A LÍNGUA FRANCA DO \\ SUPRASSENSÍVEL: SOBRE XAM ANISMO, CRISTIANISMO E TRANSFORM AÇÃO}

\begin{abstract}
Resumo
A partir da relação entre um fenômeno de possessões, denominado crise, e o cristianismo presente nas populações indígenas do baixo rio Oiapoque (região amazônica na fronteira entre o Brasil e a Guiana Francesa), o artigo pretende mostrar que, para entender eventos como este, é preciso sair das polaridades, como as que opõem cristianismo a xamanismo e os correlacionam, respectivamente, a mudança e continuidade. A proposta aqui é a de que os fenômenos sociais não são objetos com contornos nitidamente definidos, sendo ao mesmo tempo coisas corporais, metafísicas e afetivas. A significação desses fenômenos se dá nos processos de transformação ativados em (e na) relação, pelas conexões que se estabelecem e pelas conexões que carregam, de relações precedentes, os elementos em conexão. Para o tema que nos ocupará, esta proposta está plasmada na noção de língua franca do suprassensível.
\end{abstract}

Palavras-chave: Populações indígenas, Fronteira Brasil/Guiana Francesa, Xamanismo, Cristianismo, Relação, Transformação, Alteridade.

\author{
THE LINGUA FRANCA OF \\ THE SUPRASENSIBLE: ON \\ SHAMANISM, CHRISTIANITY AND \\ TRANSFORMATION
}

\begin{abstract}
Focusing on the relationship between a phenomenon of possession (known as crisis) and Christianity present in the indigenous populations of the lower Oiapoque River (in the Amazon region on the border between Brazil and French Guiana), this article shows that to understand events like this one must go beyond polarities, such as those that set Christianity in opposition to shamanism and which correlate them, respectively, to change and continuity. I propose that social phenomena are not objects with clearly defined outlines; they are at once corporeal, metaphysical, and affective things. The signification of these phenomena emerges in processes of transformation activated in (and by) relations, by the connections that are established and by the connections that carry, from previous relationships, the elements in connection. This proposal is shaped by the notion of lingua franca of the suprasensible.
\end{abstract}

Key words Indigenous populations, Brazil/French Guiana border, Shamanism, Christianity, Relationship, Transformation, Alterity. 


\section{LA LENGUA FRANCA DE LO SUPRASENSIBLE: SOBRE CHAMANISMO, CRISTIANISMO Y TRANSFORMACIÓN}

\section{Resumen}

A partir de la relación entre un fenómeno de posesiones, denominado crisis, y el cristianismo presente en poblaciones indígenas del bajo río Oiapoque (región amazónica en la frontera entre Brasil y la Guayana Francesa), este artículo pretende mostrar que, para comprender eventos como éste, es necesario salir de las polaridades, como las que oponen cristianismo a chamanismo y las correlacionan con cambio y continuidad, respectivamente. La propuesta aquí es que los fenómenos sociales no son objetos con contornos nítidamente definidos, sino que son al mismo tiempo cosas corporales, metafísicas y afectivas. La significación de esos fenómenos tiene lugar en los procesos de transformación activados en (y en la) relación, por las conexiones que se establecen y por las conexiones que conllevan elementos en conexión, de relaciones precedentes. Para el tema que nos ocupará, esta propuesta está basada en la noción de lengua franca de lo suprasensible.

Palabras clave: poblaciones indígenas, frontera Brasil/Guayana francesa, chamanismo, cristianismo, relación, transformación, alteridad. 